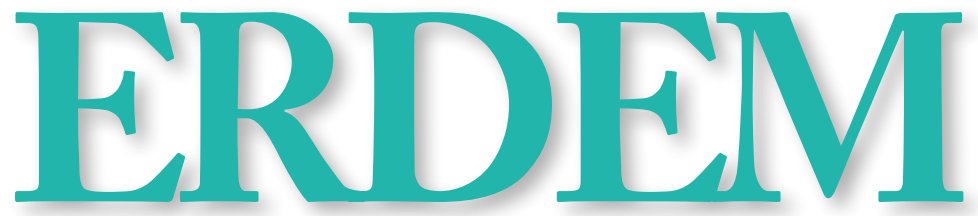

İNSAN VE TOPLUM BİLİMLERİ DERGİSİ

Münire Kevser BAŞ

Poetik Bir Metin Olarak Ebubekir Eroğlu’nun

"Yol Elçisi" Şiiri

Evşen ÇERKEŞLİ

Kurtuluş Savaşı ve Cumhuriyet İdeolojisini Edebî

Düzlemde Okumak: Dikmen Yıldızı Örneği

Hivren DEMIR ATAY

Tekerlerden Tekrarlara Gamba’da Dönüş ve Dönüşüm

Selma GÜNAYDIN

Edebî Bir Siyer Örneği Olarak Cöle İnen Nửun

Kaynakları

Mustafa GÜNDÜZ

Türk Eğitim Sisteminde Aşırı Militarist

Uygulamanın Başlaması (1926-1947)

Nagihan GÜR

Edebiyat Tarihi Yazımında Bir Kaynak Olarak

Takrizler ve Sıra Dışı İki Örnek

Osman ÖZEN - Kemalettin KUZUCU

Türk Basın Tarihinde Artin Asaduryan Matbaası ve

Matbaada Basılan Süreli Yayınlar

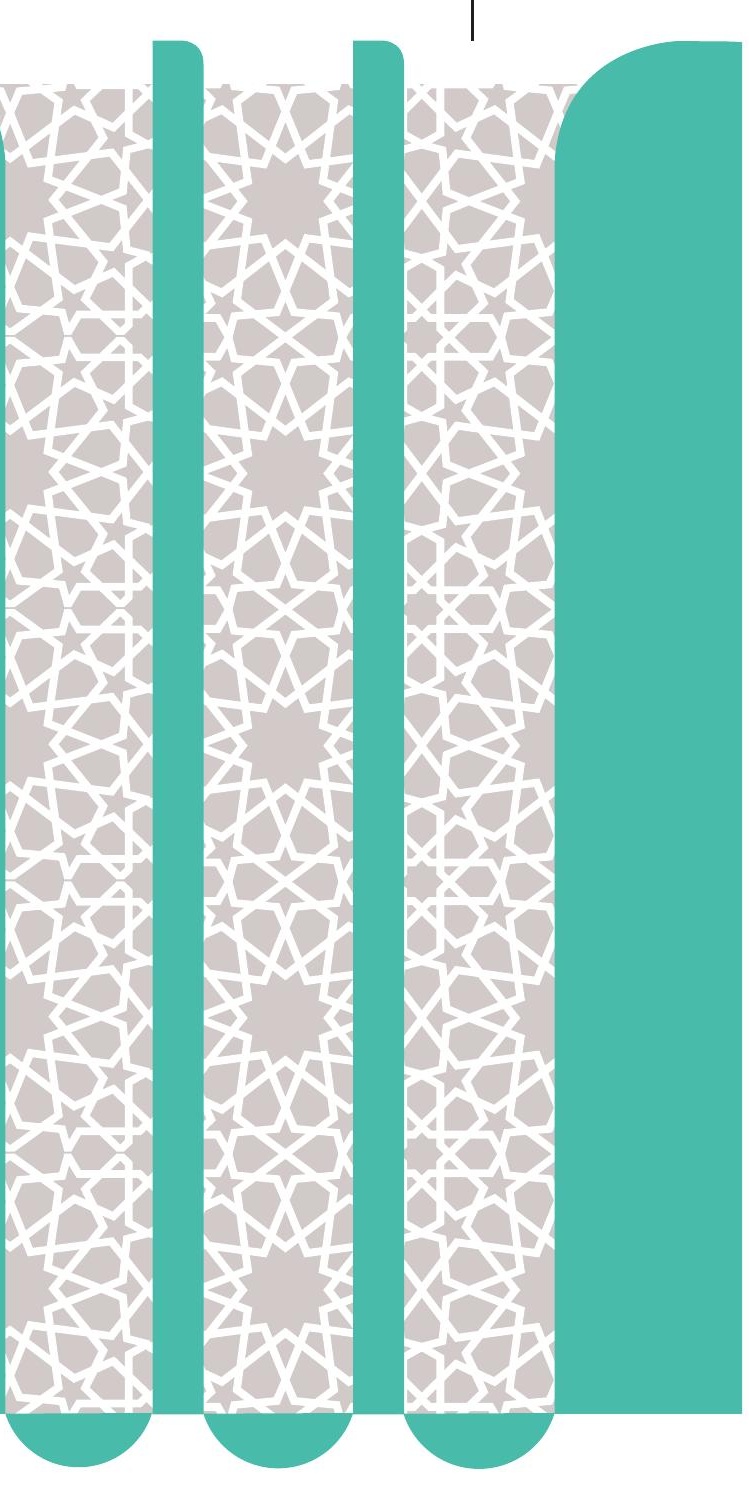




\section{ERDEM}

İNSAN VE TOPLUM BİLIMLERI DERGİSİ

JOURNAL OF HUMANITIES AND SOCIAL SCIENCES

Atatürk Kültür Merkezi tarafindan yayımlanan Erdem, insan ve toplum bilimleri alanında makalelere yer veren, hakemli bir uluslararası dergidir.

Haziran ve aralık aylarında olmak üzere yılda iki sayı çıkar.

Erdem, EBSCO, MLA ve TÜBİTAK/ULAKBİM SBVT tarafindan dizinlenmektedir.

Erdem, published by Atatürk Culture Centre, is a peer-reviewed international journal that publishes articles on humanities and social sciences.

It is published twice a year in June and December

Erdem is indexed in EBSCO, MLA and TÜBİTAK/ULAKBİM SBVT.

Görüş ve önerileriniz için editörlerimizle iletişime geçebilirsiniz.

For comments and suggestions you may contact our editors.

erdemdergisi@gmail.com 
Kültür yayıncılığın öncüsünden

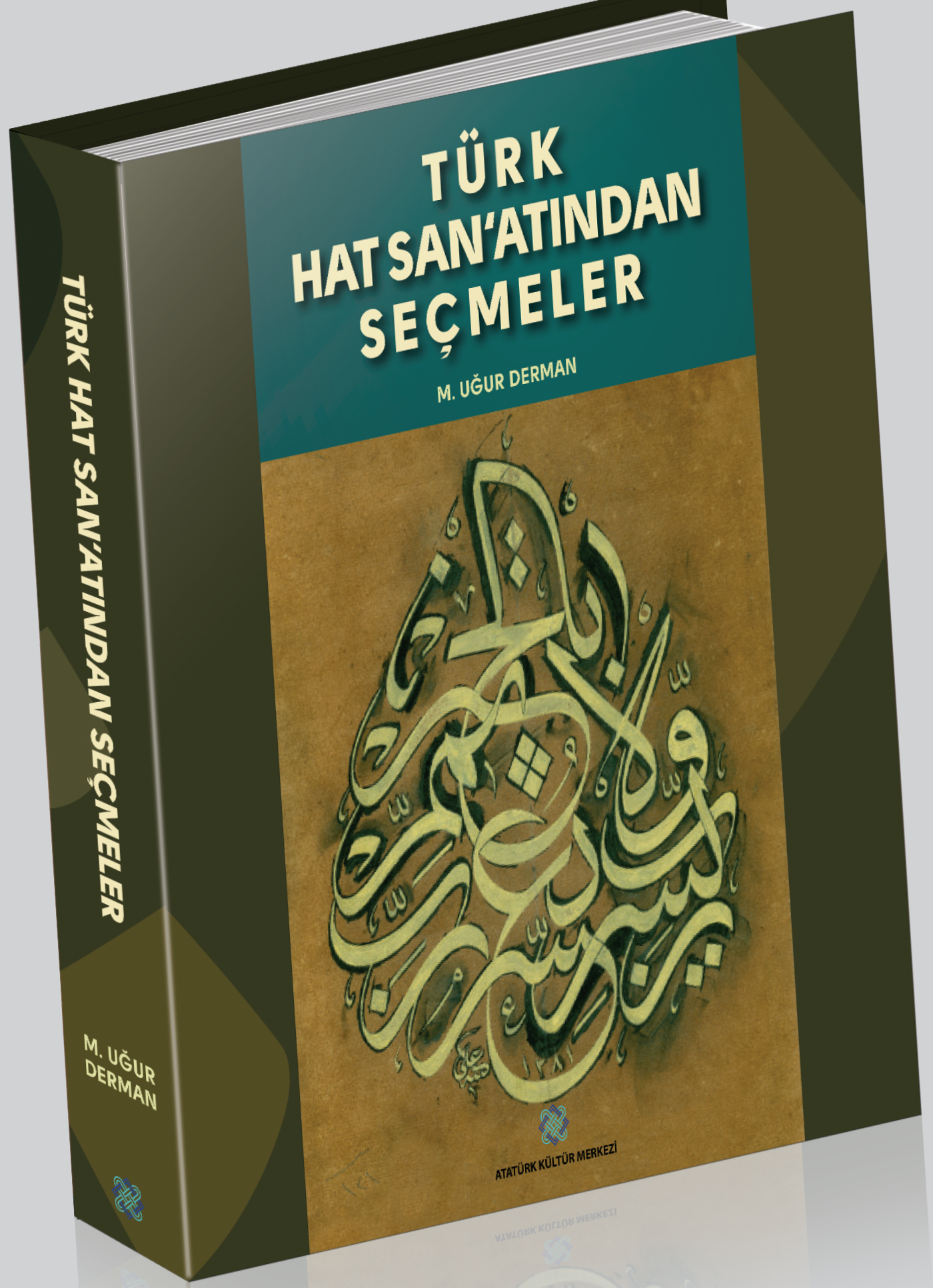




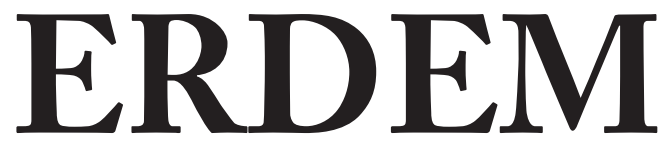

İnsan ve Toplum Bilimleri Dergisi

Journal of Humanities and Social Sciences

SAYI 71-72 • ARALIK 2016 - HAZIRAN 2017

ATATÜRK KÜLTÜR, DIL VE TARIH YÜKSEK KURUMU ATATÜRK SUPREME COUNCIL FOR CULTURE, LANGUAGE AND HISTORY

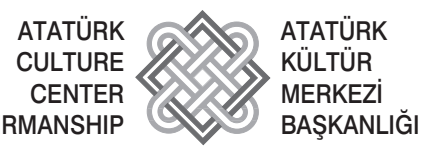




\section{ERDEM}

İnsan ve Toplum Bilimleri Dergisi

Journal of Humanities and Social Sciences

\section{DANIŞMA KURULU/ADVISORY BOARD}

Prof. Dr. Hakkı ACUN (Gazi Üniversitesi)

Prof. Dr. Hüseyin AKKAYA (Cumhuriyet Üniversitesi)

Prof. Dr. Âdem CEYHAN (Celâl Bayar Üniversitesi)

Prof. Dr. Hamza ÇAKIR (Erciyes Üniversitesi)

Prof. Dr. Mustafa ÇiçEKLER (İstanbul Medeniyet Üniversitesi)

Prof. Dr. Nurettin DEMIR (Hacettepe Üniversitesi)

Prof. Dr. Hayati DEVELI (İstanbul Üniversitesi)

Prof. Dr. Esin KÂHYA (Emekli öğretim üyesi)

Prof. Dr. Ramazan KAPLAN (Ankara Üniversitesi)

Prof. Dr. Alâattin KARACA (Muğgla Üniversitesi)

Prof. Dr. Selçuk MÜLAYIM (Marmara Üniversitesi)

Prof. Dr. Ahmet Yaşar OCAK (TOBB Üniversitesi)

Prof. Dr. Öcal OĞUZ (Gazi Üniversitesi)

Doç. Dr. Mehmet BİRGÜL (Uludağ Üniversitesi)

Doç. Dr. İdris Nebi UYSAL (Karamanoğlu Mehmetbey Üniversitesi) 


\section{ERDEM}

SAYI 71-72 • 2016-2017

Kurucu/Founder

Ord. Prof. Dr. Aydın SAYILI (1913-1993)

Sahibi/Owner

Atatürk Kültür Merkezi adına Başkan

Zeki ERASLAN

Yayın Kurulu/Editorial Board Prof. Dr. Muhammet HEKIMOĞLU

Prof. Dr. Güray KIRPIK

Doç. Dr. Bilal ÇAKICI

Uzm. Ömer ÇAKIR

Yüksek Kurum Uzm. Murat Altan ERİK

Yüksek Kurum Uzm. Yrd. Ömer GÖK

Yazı İşleri Müdürü/Managing Editor

Başkan Yardımcısı Şaban ABAK

Editörler/Editors

Yüksek Kurum Uzm. M. Altan ERİK

Uzm. Yrd. Ömer GÖK

İngilizce Özetler/English Abstracts Ayşegül ÖZDOĞAN

Yönetim Yeri/Managing Office Ziyabey Caddesi No: 19 Balgat 06520 Ankara, TÜRKIYE

Tel.: +903122843425 erdemdergisi@gmail.com www.akmb.gov.tr

GrafikTasarım/Graphic Design Grafiker Grafik-Ofset Matbaacılık

Reklamcılık San. ve Tic. Ltd. Şti Mustafa YAVUZ

Bask1/Print

Grafiker Grafik-Ofset Matbaacılık Reklamcılık San. ve Tic. Ltd. Şti. www.grafiker.com.tr

Yayın Türü/Publication Type Süreli Yayın

Yılda İki Sayı Çıkar ISSN 1010-867X

Baskı Tarihi/Print Date Haziran 2017
Değerli okurlar,

Erdem'in 71 ve 72 . sayıları ile karşınızdayız. Ülkemizde yaşanan hain darbe girişimi, tüm kamu kurumlarını derinden etkilediği gibi Kurum olarak bizim çalışmalarımızı da sekteye uğratmıştır. Bu sebeple Haziran 2016'da çıkaracağımız 71. sayıyı ancak 72. sayı ile birlikte siz değerli okuyucularımıza takdim ediyor, bundan sonra böyle gecikmelerin yaşanmamasını umuyoruz.

Sevgili okurlar, bu sayımızda edebiyat, basın ve eğitim tarihini ilgilendiren yazıların yanı sıra Selma Günaydın’ın “Edebî Bir Siyer örneği Olarak Çöle İnen Nur'un Kaynakları"nda Necip Fazıl Kısakürek; Doç. Dr. Münire Kevser Baş'ın "Poetik Bir Metin Olarak Ebubekir Eroğlu'nun 'Yol Elçisi' Şiiri”nde ise Ebubekir Eroğlu gibi kültür dünyamızın öncü isimlerinin eserleriyle ilgili inceleme yazılarını da muhtevi yedi makaleye yer verilmiştir. Kültür ve edebiyat tarihimize 1ş1k tutan birbirinden değerli bu makalelerin siz değerli okurlarımız tarafindan ilgiyle karşılanacağını ümit ediyoruz.

Dün olduğu gibi bugün de Erdem dergisi niceliği değil, niteliği önemseyen anlayışını devam ettiriyor. İki sayı birlikte çıkarmamıza rağmen bu anlayışımızdan yine taviz vermedik. Onlarca makaleden oluşan ancak okunmayan dergiler arasinda olmaktansa sayica az fakat özgün ve yetkin makaleler içeren bir dergi olmak tercihimizdir. Bu şiarla hareket ediyor ve makale seçimlerinden hakem atamalarına değin birçok aşamayı titizlikle yürütüyoruz. Bu noktada sizlerden gelecek eleştirilere de açık olduğumuzu bildirmek isteriz. Daha iyiye ve güzele yol almak için tüm yazar ve okurlarımızin desteğine talibiz.

Gelecek sayılarda buluşmak dileğiyle.

İyi okumalar,

\section{Şaban ABAK}




\section{ERDEM}

Say1 71-72 • Aralık 2016-Haziran 2017

\section{İÇINDEKILER/CONTENTS}

\section{Münire Kevser BAŞ}

Poetik Bir Metin Olarak Ebubekir Eroğlu'nun “Yol Elçisi” Şiiri

Ebubekir Eroğlu's Poem "Yol Elçisi” As a Poetic Text

\section{Evşen ÇERKEŞLI}

Kurtuluş Savaşı ve Cumhuriyet İdeolojisini Edebî

Düzlemde Okumak: Dikmen Yıldızı Örneği

The War of Independence and The Republican Ideology in

Literary Level: Dikmen Yıldizı Example

\section{Hivren DEMIR ATAY}

Tekerlerden Tekrarlara Gamba'da Dönüş ve Dönüşüm

From Bicycles to Cycles: Return and Transformation in Gamba

\section{Selma GÜNAYDIN}

Edebî Bir Siyer Örneği Olarak Çöle İnen Nư'un Kaynakları

Roots of Çöle İnen Nur As a Literary Example of Siyar

\section{Mustafa GÜNDÜZ}

Türk Eğitim Sisteminde Aşırı Militarist Uygulamanın Başlaması (1926-1947)

Starting Excessive Militarism in The Turkish Educational System (1926-1947)

\section{Nagihan GÜR}

Edebiyat Tarihi Yazımında Bir Kaynak Olarak Takrizler ve Sıra Dışı İki Örnek

Takriz Texts as a Source of Literary History Writing and Two Unusual Examples

\section{Osman ÖZEN - Kemalettin KUZUCU}

Türk Basın Tarihinde Artin Asaduryan Matbaası ve Matbaada Basılan Süreli Yayınlar ..... 117-138 Periodical Publishing Works and Artin Asaduryan Press in Turkish Press History

Yayın İlkeleri.

Editorial Principles 


\title{
Tekerlerden Tekrarlara Gamba'da Dönüş ve Dönüşüm
}

\author{
HIVREN DEMIR ATAY*
}

\begin{abstract}
ÖZ
Günümüz Türk edebiyatının üretken yazarlarından Cemil Kavukçu'nun 2005 yılında yayımlanan Gamba başlıklı romanı, özgürleşmek amacıyla bisikletleriyle doğa yolculuğuna çıkan, fakat geride bırakmayı umdukları hayatlarına kısa sürede "dönüş" yapan dört arkadaşı konu edinir. Kavukçu’nun öteki yapıtlarında da sıklıkla karşılaştığımız dönüş izleği, Gamba'da tematik ve mecazi düzlemlerde yorumlanabilecek üç temel dönüş hareketi şeklinde yansıma bulur: Bisiklet tekerlerinin dönüşü, dört arkadaştan birinin çocukken rüyalarına giren korkunç yaratık Gamba'nın y1llar sonra dönüşü ve karakterlerin yolculuk öncesi yaşamlarına dönüşü. Bu makale, söz konusu hareketlerin psikolojik ve toplumsal dinamiklerini çözümlerken, Gamba’nın, Kavukçu'nun yapıtlarındaki edebî döngüselliği de anlamlandırmaya yarayacak temsilî bir metin olarak yorumlanabileceğini öne sürmektedir. Makalede Kavukçu'nun yapıtları üzerine yapılan çalışmalarda sıklıkla üzerinde durulan yalnızlık ve yabancılaşma izleklerine psikanalitik bir bakış açısıyla yaklaşılmaktadır. Karakterlerin kişisel tarihleri kadar, "uygarlığın huzursuzluğu” nu da temsil eden söz konusu üç dönüş hareketi, Kavukçu'nun "Yazma Sıkıntısı" başlıklı denemesinde edebî üretimin kaynağ1 olarak gördüğü sıkıntı duygusuyla ilişkilendirilmektedir. Bu çerçevede, Gamba'da temsil edilen ve Freud'un "bastırılanın dönüşü", "yineleme zorlantısı" ve "tekinsizlik" gibi kavramları aracılığıyla açımlanan ruhsal yaşantı, Kavukçu’nun resmettiği yazma ânının ardındaki dinamikleri de açıklayabilir. Sonuç olarak makale, Kavukçu'nun benzer karakter, mekân ve temalara tekrar tekrar dönüşünün nedeninin Gam$b a$ 'daki dönüşlerle aynı eksende düşünülebileceğini öne sürmektedir. Buna göre, her iki durumda da dışına çıkılması imkânsız bir çemberin içinde var olmanın tek yolu çemberin sınırlarını zorlamaktır.
\end{abstract}

Anahtar sözcükler: Dönüş, dönüşüm, tekrar, uygarlığın huzursuzluğu, tekinsizlik, Sigmund Freud, Cemil Kavukçu, Gamba

* Yrd. Doç. Dr., Mersin Üniversitesi, Karşılaştırmalı Edebiyat Bölümü/MERSİN

E-posta: hivren@mersin.edu.tr 
$\mathrm{T}$ ürk edebiyatında özellikle öykü türüne katkılarıyla tanınan Cemil Kavukçu'nun 2005 yılında yayımlanan romanı Gamba, yazarın öteki yapıtlarında da karşılaştığımız kent hayatından kaçış, taşra sıkıntısı ve özgürleşme arayışı gibi konular etrafinda şekillenir. 1980'lerden günümüze dek yayımlanan öykülerinde kasabanın açmazlarını, bireylerin kent hayatının yapaylıkları içindeki kıstırılmışlıklarını, gemi adamlarının bunalımlarını öykü türüne özgü inceliklerle ortaya koyan Kavukçu, Dönüs (1998) ve Suda Bulanık Oyunlar (2004) başlıklı romanlarında benzer temaları bir içsel yolculuk izleğine bağlı kalarak yansıtır. Gamba da Kavukçu edebiyatındaki bu ana hatların açıklıkla takip edilebileceği bir romandır. Özellikle yazarın öteki yapıtlarına aşina bir okur, Gamba'da yer yer öykülerdeki, yer yer romanlardaki karakterleri, mekânları, dil ve üslubu çağrıştıran birçok pasajla karşılaşacaktır.

Söz konusu edebî döngüsellik, tematik düzlemden mecazi düzleme taşınabilecek üç dönüş hareketiyle birlikte düşünüldüğünde, Gamba'nın, Kavukçu edebiyatının önemli niteliklerini ortaya koyan temsilî bir metin gibi işlediği öne sürülebilir. Bu hareketlerden birincisi, özgürleşme arzusunun peşinden giderek doğayla baş başa kalmak isteyen ve bisiklet yolculuğuna çıkan dört arkadaşın pedalları çevirerek döndürdükleri tekerlerin hareketidir. Bu, karakterlerin fiziksel olarak güçlerini kanıtlama çabalarının yanında, yolculuğu, özgürlük için verilen kişisel bir mücadelenin sembolü olarak belirginleştirir. İkinci hareket, dört arkadaştan biri olan Asım'ın çocukken, özellikle de ateşlendiğinde rüyalarına giren Gamba’nın bir korku figürü olarak dönüşüdür. Kuş-insan karışımı bu yaratığın söz konusu yolculukta tekrar ortaya çıkışı, Sigmund Freud'un "bastırılanın dönüşü" adını verdiği bilinçdışı mekanizmanın bir temsili gibi görünmekle birlikte, bu mekanizmayı, "uygarlığın huzursuzluğu” çerçevesinde Asım'ın yaşadığı bireysel travmanın ötesine taşımak mümkündür. Üçüncü hareket ise karakterlerin heyecanla çıktıkları yolculuktan hayal kırıklıkları içinde eski hayatlarına dönüşüdür. Telefonlarını kapatıp çadırda doğayla baş başa kalma kararı vermiş olsalar da onları var eden yaşam alanları ve birlikte yaşadıkları insanlar -eş, anne ya da sevgili- kolay kolay geride birakılamayacaktır.

Bu yazı, söz konusu üç dönüş motifinin izini sürerken Kavukçu edebiyatının önemli özelliklerinden biri olan karakter, mekân ya da tema tekrarlarının bu motiflerle ilişkisini tartı̧̧acaktır. Yazı, Gamba'yı psikanalitik kavramlarla çözümleyerek Kavukçu yapıtlarının psikanalizle kurduğu güçlü ilişkiye dair bir örnek sunmayı amaçlamaktadır. Kavukçu, modern insanın bunalımlarını gerçekçi bir bakış açısıyla ele alan bir yazar olarak sıklıkla tartı̧sılmıştır. Özellikle yalnızlık ve yabancılaşma kavramları yazarın edebî dünyasını çözümleyen çalı̧̧malarda merkezî bir rol üstlenmiştir. Örneğin Melike Koçak, Kavukçu'nun 
öykü kişilerinin modernleşme karşısında sıkışıp kaldıklarını söyler ve ekler: "Yalnızdırlar, her şeye ve herkese yabancıdırlar, yabancı değilmiş gibi davranmaya çalışır, kendilerinden daha da uzaklaşırlar" (2008: 20). Zerrin Eren, Kavukçu'nun üç öyküsünde izini sürdüğü metinlerarası çerçeve tekniğini açımlarken yazarın bu tekniği kullanma amacının "yalnızlık ve yabancılaşma konularını çarpıcı bir biçimde ortaya koymak" olduğunu söyler (2008: 8788). Bülent Cercis Tanrıtanır ve Burcu Tütak’nn Gamba'yı Amerikalı yazar J. D. Salinger'ın Çavdar Tarlasında Çocuklar romanıyla karşılaştırdıkları yazıları, her iki yapıtın da modern dünyada bireylerin yalnızlık ve yabancılaşma nedeniyle yaşadığı trajediyi anlattığını öne sürer. Tanrıtanır ve Tütak’a göre, yaşanan trajedinin nedeni, bireylerin yarattıkları maddi değerler nedeniyle öz benliklerinden ve içinde yaşadıkları toplumdan uzaklaşmalarıdır (2015: 33).

$\mathrm{Bu}$ çalışmaların örneklediği üzere, genel olarak Kavukçu edebiyatında ve özel olarak Gamba'da yalnızlık ve yabancılaşma temaları tartışmaya açılmış, ancak bu temalar psikanalitik kavramlarla yorumlanmamıştır. Oysa Gamba'da olay örgüsünün önemli bir öğesi olan düşler ve sanrılar, Freud'un bilinçdış1 kavramını metni yorumlamaya yarayacak bir araç olarak öne çıkarmaktadır. Kavukçu'nun "Yazma Sıkıntısı" başlıklı yazısının da benzer düşsel öğeler içermesi, Gamba'daki bastırma mekanizmasının estetik bir alana taşınabileceğini göstermektedir. Bu yazı, dönüş izleği etrafinda biçimlenen tematik bir yorumlamadan edebî yaratıcıllğın anlamına uzanan estetik bir alana geçmeyi hedeflemektedir. Böylece Kavukçu edebiyatı üzerine yapılan çalışmalarda tematik boyutta tartışılan yalnızlık ve yabancılaşma gibi kavramların yazarın yaratıcılık süreciyle ilişkisi de değerlendirilecektir.

Bu amaçla, yazının ilk bölümünde, roman karakterleri için bisiklet yolculuğunun anlamı tartısmaya açılacaktır. Bisiklet tekerlerinin dönüş hareketlerinin karakterlerin özgürlük arayışları açısından ne ifade ettiği açımlanacak, kent, kasaba ve kadınların bu arayı̧̧ sırasında kazandıkları anlam ele alınacaktır. İkinci bölümde, Gamba figürü Freud'un "tekinsizlik" ve "bastırılanın dönüşü" kavramları ekseninde yorumlanacaktır. Roman karakterlerinden biri olan Asım'ın korkuları, Freud'un "uygarlığın huzursuzluğu" kavramı çerçevesinde tartışılacaktır. Yazının son bölümünde Gamba’nın dönüşüyle yazarın dönüşü arasındaki ilişki, Kavukçu'nun "Yazma Sıkıntısı" başlıklı yazısından hareketle ele alınacak, Gamba’nın yazarın öteki yapıtlarıyla kurduğu güçlü bağ ortaya konacaktır.

\section{Tekerlerin Dönüşü: Bisiklet ve Özgürlük Arayışı}

Asım'ın, bireyselliğini duyumsamak ve rutin hayatından sıyrılmak amacıyla, emeklilik sonrası tek başına çıkmayı düşündüğü bisiklet yolculuğuna kendi- 
siyle aynı kurumda çalışan Cevat ve Turgay'la Cevat'’n büyüdüğü kasabadan arkadaşı Nurbay da katılır. Birbirlerini çok da iyi tanımayan bu dört kişinin bisiklet ve çadırla yapılacak bu yolculuğa heves etme nedenleri farklıdır. Asım'ın amacı, yıllardır çalıştığı köhne devlet kurumunun yarattığı bıkkınlıktan kurtulmak ve evliliğinde yaşadığı sorunlardan uzaklaşmaktır. Asım, kendisinden kaynaklanan nedenlerle çocuk sahibi olamamış, bu durumun karısı Nezahat'le ilişkisini olumsuz etkilediğini düşünmüştür. On yıl önce, evliliklerinde yaşadıkları bir krizin ardından "[v]arış noktası olmayan ve geri dönülmeyecek bir yolculuk" düşlemiş fakat bunu gerçekleştirememiştir (2006: 20). Şu an çıktı̆̆ı yolculuğun ise bir varış noktası olduğunun ve mecburi bir dönüş içerdiğinin farkındadır. O yüzden de kendini "gecikmiş bir prova” y1 izler gibi hisseder (2006: 20).

Cevat'ın bu yolculuğa çıkma sebebi evli bir kadınla yaşadığı aşkı geride bırakma arzusudur. İşyerindeki toplantılar sırasında tanıştığ 1 Şebnem’e tutkuyla bağlı olan Cevat, bu yolculuk sırasında tutkularından kurtulmayı ummaktadır. Ankara'ya dönüp anlamlı bir hayat kurmak, işyerindeki arkadaşlarıyla mesafesini artırmak, böylece akıntıya kapılıp gitme tehlikesini ortadan kaldırmak istemektedir (2006: 76).

Turgay, Asım'ın bisiklet turu planını başlangıçta yadırgamış, onca zaman arazilerde çalışmış, hayatı çadır ve karavanlarda geçmiş Asım'ın "izinli olduğu gün kenti yürüyerek dolaşmaya çıkan bir postacı" gibi davrandığını düşünmüştür (2006: 102). Ne var ki, Turgay'ın hayatı da kendi içinde düzenli olmakla birlikte son derece yüzeysel ve yıpratıcıdır. Anlatıc1, Turgay'n "[e]viyle işyeri arasına çekilmiş görünmeyen bir tel” olduğunu söyledikten sonra ekler: "[B]u tel boyunca hareket edebilen halkalı bir ip de (neden kravatı olmasin ki) boynuna bağlı. Yaşamı, bu hat boyunca gidiş gelişlerle sınırlanmış" (2006: 108). Hem bu tekdüzelik hem de karısı Sema’yla yaşadığı güvensiz ilişki, Turgay'in da kendini bu yolculukta bulmasıyla sonuçlanmıştır.

Annesiyle kasabada yaşayan Nurbay, hapse girip çıkmış, maddi yetersizlikler yüzünden evlenmemiştir. Artık bir değişikliğe ihtiyacı olduğunu ve kendisini yorarak acısını bedeninden çıkarmanın iyi geleceğini düşündüğü için Asım, Cevat ve Turgay'a eşlik eder. Döndüğünde, genel olarak daha dayanıklı ve annesine karşı daha anlayışlı olmayı ummaktadır (2006: 130-131).

Dört karakterin her biri kendi yaşamındaki tıkanma noktaları üzerine düşünürken bisiklet, yolculuklarının en önemli öğesi olarak belirir. Pedal çevirirken kurdukları diyaloglar, yokuş çıkma ve inme sırasında zihinlerinden geçenler ve yolculuk boyunca doğayla kurdukları ilişki, bisiklete sembolik bir anlam yüklediklerini gösterir. Yolculukları Antalya'da, Konyaaltı'na uzanan 
yokuşu inmeleriyle başlar. Cevat, Turgay ve Nurbay, "kendilerini iniş sarhoşluğuna" bırakırlarken Asım çok daha temkinlidir (2006: 136). Kamp alanına geldiklerinde geride kalan Asım'ı birlikte izlerler: "Bir ritim tutturmuş, huzur içinde çeviriyor pedalları” (2006: 138). Gerek yokuştan vecd hâlinde kendini bırakan üç karakter, gerekse de kontrollü ama huzurlu bir biçimde pedal çeviren Asım, bir inişle başlamanın rahatlığı içinde bu yolculuğu gerçekleştirme kararlılıklarını ortaya koyarlar.

Zorluklarla yüzleşmenin sembolü olarak okunabilecek yokuş çıkma eyleminin temsilleri ise karakterlerin kendi yaşamlarındaki zorluklarla mücadele etme tarzlarıyla kimi parallelikler gösterir. Yokuş çıkarken Cevat'ın zihninden geçenlerin anlatıldığı bir bölümde, "bunalan ruh hareket ister" ilkesiyle motive olduğu anlaş1ır (2006: 41). Sigara, içki, uykusuzluk ve düzensiz bir yaşamın yorduğu ciğerleri tırmanışı iyiden iyiye zorlaştırsa da Turgay, bakışlarıyla Cevat'ın her yokuşu aşabileceğini söyler; çünkü Cevat, sarpa saran bir ilişkiyi sürdürmekte, bir anlamda yaşamında zaten zor bir yokuşu tırmanmaktadır (2006: 39). Cevat, benzer bir metaforik ilişkiyi bu kez Nurbay'ın hayatı ekseninde kurar. Ona göre Nurbay, hayattaki birçok zorluğa nasıl dayandıysa, bu yokuşa da öyle dayanmıştır ve Nurbay'ın direnci, onun saflı̆̆1 ve temizliğiyle de yakından ilişkilidir (2006: 44). Asla kaçamayacağını, daha uzun yolculuklara çıkamayacağını bilse de bu geçici hesapsızlık hoşuna gitmektedir.

Bisikletle yol almanın "sessiz bir koşu", bir kendini unutma deneyimi olduğunu düşünen Nurbay (2006: 131), "kendi gücüyle", "göre göre" ve "sindire sindire" gitmenin tadını çıkarır (2006: 132). Öte yandan Turgay'ın bisikletini "kendi cesedini sürükler gibi" sürüklemesi (2006: 46), hayatındaki yüklerden kurtulmak konusunda iradesini yeterince devreye sokamadığı iması taşır. $\mathrm{Bu}$ imanın arka planında ise Turgay'ın iş hayatındaki teslimiyetçi tavrı, kendi iradesini ortaya koyamaması, bunun için eşi Sema tarafindan da eleştirilmesi vardır. Bununla beraber, bu dört karakterin hepsi bireysel bir özgürlük mücadelesi vermektedir ve bisikletle kurdukları ilişki farklılıklar gösterse de hepsi dönüşme arzusu içindedir. Karakterler bu dönüşümün hızla gerçekleşemeyeceğinin farkındadırlar. Buna rağmen, Asım’ın "prova” dediği bu macera onlar için bir kesit olarak bile kıymetlidir.

Batı edebiyatında bisiklet üzerine yazdığı yüksek lisans tezinde Nanci J. Adler, Arthur Conan Doyle'dan H. G. Wells'e, Ernest Hemingway'den F. Scott Fitzgerald'a birçok yazarın metinlerinde bisikletin nasıl temsil edildiğini incelemiş ve bisikletin yalnızca bir "ulaşım" değil aynı zamanda bir "dönüşüm" aracı olduğu sonucuna ulaşmıştır (2012: 5). Batı edebiyatında bisiklet sıklıkla kişisel ve toplumsal dönüşümün katalizörü ya da simgesi olarak kullanılmıştır 
(2012: 2-3). Özellikle on dokuzuncu yüzyılın sonlarından itibaren daha fazla insan için ulaşılabilir hâle geldiğinden, arabanın aksine bisiklet kullanmak belli bir ekonomik sınıfin değil, geniş bir insan nüfusunun aktivitesi olarak belirmiştir (2012: 4).

Alon Raab ise Lev Tolstoy'dan Necib Mahfuz'a dünya edebiyatından birçok örneği ele alarak Adler'inkine yakın gözlemlerde bulunur. Bisikletin kazayla, savaşlarla, şiddet ve sömürüyle ilişkili temsillerinden de örnekler sunmakla birlikte Raab, edebiyatta daha çok bireyin kendisini keşfetmesinin kaynağ 1 (2012: 23), bağımsızlaşma ve özgürleşmenin bir aracı (2012: 27) olarak resmedildiğini söyler.

Gamba da iki teker üstünde dönüşüm yaşayacağını düşünen dört arkadaşın romanı olarak başlar. Bisiklet, yalnızca kentliyle kasabalıyı değil, insanla doğayı da buluşturan dönüştürücü bir araç olarak temsil edilir. Nurbay, "her şeyi göre göre, koklaya koklaya" gitmekten aldığı keyifle beraber doğanın eğiticiliğgine duyduğu inancı da dile getirir: "Bu yolculukta ne kadar kaplumbağaya şaştıysam o kadar da bunu önemseyen kendime şaştım. Doğanın beni eğiteceğine, terbiye edeceğine, en önemlisi de sabrı öğreteceğine inandım" (2006: 50). Nurbay'ın sözleri, Adler ve Raab'in gözlemleriyle uyumlu bir biçimde, eşitleyici, özgürleştirici ve yavaşlatıcı bir bisiklet tanımı sunar. Ne var ki Gamba'da bu dönüşüm karakterlerin hayatlarına sızamayacak kadar sınırlı ve yapay kalır. Sözü edilen değerli anlar, geride bırakılan sorunların geçici olarak görmezden gelinmesiyle yaşanabilmiş, nihayetinde serüven "normal hayat"a "dönüş"le sonuçlanmıştır (2006: 335).

Karakterlerin kendi hayatlarındaki sıkıntılardan kurtulmak için yaşamayı umduğu dönüşüm, psikolojik ve toplumsal anlamda dar kalıplar içinde biçimlenmelerinden kaynaklanmaktadır. Roman boyunca bu dört karakterin başka insanlar hakkındaki yargıları, özellikle de kadınları, eril dili fütursuzca kullanarak kategorize etmeleri, bizzat kendilerinin eşitlik ve özgürlük fikrinden yoksun olduklarını gösterir. Bisikletinin pedallarını huzur içinde çeviren Asım'ın bir köyde mola verme önerisi karşısında hissettiği huzursuzluk, bu durumun bir örneğidir:

Köy ve köylülerden olabildiğince uzak durmaya çalışan Asım Eray ('Bir kere herifler pis, tembel; çıkarcılık ve bencillikleri de caba.') o köyde mola vermeye karşı çıkmıştı, köyü geçtikten sonra güzel bir ağaç gölgesinde oturup soluklanırlardı. Ama Turgay tutturmuştu: "Şu kahvenin önündeki çınarın altında birer çay içelim abi, yemezler ya adamı."Yemezler tabii, Asım Eray da onu yerler diye korkmuyordu; bu tür muhabbetleri sevmiyordu, o kadar. Ölçüp biçerek, sinsi bakışlarla süzeceklerdi onları; sorular soracaklardı. Tedirginlik bulaşacaktı her yanlarına, ne gereği vardı (2006: 37). 
Asım’ın zihninde köylüler bütün bu olumsuz niteliklerle kodlanmıştır. Romanın bir başka noktasında Turgay'a dönüp, “o, 'milletin efendileri' dediklerin var ya, onların bir sözüne bile inanmayacaksınız” (2006: 51) dediğinde, yine sınıflayıcı bakışını son derece net bir biçimde dile getirir. Nurbay'a göre Asım'daki bu huzursuzluğun nedeni, sorunlarını çözmüş gibi duran dingin bir adamın görünmeyen yüzüdür. Asım hayatı boyunca duvarın ardındaki öteki Asım'ı yatı̧̧ırmaya çalışmıştır (2006: 59). Nurbay'ın, bunalımdan kurtulmak için ölümü seçen arkadaşı İlhan’la Asım arasında gördüğü benzerlik de Asım'ın kendisini dönüştürmek için çıktığı yolculukta başarılı olamayacağının işaretlerini verir.

Yaşam alanları - kent ya da kasaba - işyerleri, rutin hayat, dört erkeğin "kaçış provası"nın önemli nedenleri olsa da kadınlar, bütün bu nedenleri de buluşturan en güçlü etken olarak belirir. Aralarındaki konuşmalarda kadınlar küçümsenir, cinselliğin nesneleri ve özgürlüklerin sınırlayıcıları olarak temsil edilirler. Örneğin Turgay'ın geçmişte onunla aynı iş yerinde çalı̧̧mı̧̧ birinin İngiliz eşi için yaptığı yorumlar, "ablak yüzlü", "iri yapılı", "sevimsiz" gibi s1fatlarla doludur. Turgay benzer çizgileri eşi Sema'da da görmektedir (2006: 105). Yolculuğu bitiren yine kadınlar olmuş, Asım, karısı Nezahat'le, Cevat ise sevgilisi Şebnem'le yaptığı telefon görüşmesinden sonra dönmeye karar vermiştir. Nurbay, "büyüyü kaçıran kadınlar" betimlemesiyle bisiklet üstünde özgürleşmenin sınırına kadınları yerleştirir.

Yolculuk sırasında karşılarına çıkan Meltem, zihinlerindeki kalıbı kırmalarını, biraz olsun dönüşebilmelerini sağlayabilecek bir karakterken, çarçabuk cinsel bir arzu nesnesi hâline gelir. Meltem, kaçma isteğinin erkeklere özgü olmadığını gösterir. İstanbul'dan kaçmış, Kaş’a yerleşmiş ama aslında bunun bir kaçış olamayacağını fark etmiştir. "Beni onaracak tek şeydi gitmek... Ama gidemedim... Yani, önce gittiğimi sandım da, sonra bunun bir yerden başka bir yere sıçramak olduğunu anladım" der. İçini çekerek ekler: "Gitmek başka bir şey. Attilâ İlhan'ın dediği gibi, yola çıkılınca gidilir, büyük kentler, büyük aşklar çı̆̆lık çı̆̆lı̆̆a terk edilir” (2006: 271). Böylece romanın eril dil ve dünyasına ilk kez bir kadın, kendi özgürlük arayışını dile getirerek girer; fakat bu sahne, kalıcı bir dönüşümle sonuçlanmayan bir kesit olarak kalır.

\section{Bastırılanın Dönüşü: Arkeolojik Bir Kazı Nesnesi Olarak Gamba}

Roman, karakterlerin içselleştirmediği duygu, düşünce ve arzuların yapaylıklarını ortaya koyarken karakterlerin belli kalıplarla biçimlenmiş olmaları bu yapaylıkta önemli bir etken olarak belirir. Ancak ruhsal yaşamın, Freud'un yorumuyla, arkeolojik bir kazı gerektiren tarihi, bu kalıplardan bağımsız de- 
ğildir. Karakterler geçmişleriyle, bastırılmış dürtü ve travmalarıyla birlikte var olurlar. Asım'ın rüyalarına giren Gamba, bu türden bir travmayı temsil eden bir tekinsizlik figürü olarak düşünülebilir. Asım'ın bireysel tarihi, okurun bir arkeolog gibi çalışmasına olanak verecek kadar ipucu sunmaz. Bununla beraber, çocukken Asım’n rüyalarına giren Gamba'nın yıllar sonra “dönüş"ü, bütün karakterlerin paylaştığı iç sıkıntısını, kuşatılmışlık duygusunu ve nihayetinde uygarlığın yarattığı huzursuzluğu sahneye koyar.

Gamba, Asım'ın, bu garip yaratığa çocukken verdiği isimdir. Kırk yıldan uzun bir aradan sonra, Turgay'la paylaştığı çadırda Gamba'yı tekrar rüyasında gördüğünde, uyku tulumunun içinde olduğunu unutmuş, "kıskıvrak bağlanmış ya da kefene sarılmış, karanlık bir tabutta yattığını sanmıştı[r]" (2006: 16). Gamba, Asım için “uğursuz bir haberci” gibidir (2006: 17). Tanımadığı puslu bir sokakta belirir; ama bir taraftan da bulunduğu yerin her ayrıntısını bildiğini fark eder (2006: 17-18). Bu mekân, çizgi roman Teksas'taki kasabalara benzer. Gamba’nın o sokakta karşısına çıkacağını bilse de yürümeye devam eder: "Çünkü, geri dönse de Gamba ile karşılaşacağını bilirdi. Bütün çıkış yollarının kapandığı bir tuzağa düşmüştür artık” (2006: 18).

Freud, "tekinsiz" i "korku yaratan şeylerin eskiden beri bilinen ve yabancı olmayan bir şeye geri uzanan türü" olarak tanımlar (1999a: 326). "Unheimlich" sözcüğünün farklı dillerdeki anlamlarını inceleyerek özellikle tanıdık/eve ait olanla (heimlich), yabancı/eve ait olmayanın (unheimlich) buluşma noktalarının üzerinde durur. Buna göre, eve ait olan, aynı zamanda yabancılardan sakınılan, gizli şey anlamında kullanılmaktadır (1999a: 331) ve bu temel fikir bastırma ve tekrarla yakından ilişkilidir (1999a: 347). Freud, "tekinsiz gerçekte yeni ya da yabancı bir şey değil ama akıl için bildik ve köklü olan ve yalnızca bastırma süreciyle akla yabancılaştırılmı̧̧ bir şeydir" der (1999a: 347). Bu şey yinelendiğinde, başlangıçta korkutucu olup olmadığı da önemini yitirecektir (1999a: 347). Freud, tekrarın yarattığ 1 tekinsizlik duygusuna örnek olarak, rüyasında kendisini dönüp dolaşıp hep aynı sokakta buluşunu verir (1999a: 343). Bir İtalyan taşra kasabasının 1ssız sokaklarında yürürken içinde kendini bulduğu sokakta "küçük evlerin pencerelerinde boyalı kadınlardan başka bir şey" görünmediğini fark ettiğinde tedirgin olmuş, aceleyle oradan çıkmaya çalışmış, dolambaçlı bir yol kullanarak hızla uzaklaşmasına karşın üçüncü kez kendisini aynı noktada bulmuştur (1999a: 343). Freud'un, istenmeyen bir durumun yinelenmesi karşısındaki çaresizlik ve tekinsizlik duygusuna verdiği bir başka örnek de şudur: "[i்]nsan sise yakalanarak bir dağ ormanında yolunu yitirdiğinde işaretli ya da bildik yolu bulma konusundaki her girişim insanı tekrar tekrar bazı özel işaretlerden tanıyabileceği tek ve aynı noktaya getirebilir" (1999a: 344). 
Asım'ın rüyasında Gamba'yla karşılaştığı "puslu” sokak, tam anlamıyla Freud'un tanımladığı türden bir tekinsizlik sahnesidir. Asım, başlangıçta kendisine bütünüyle yabancı gelen bu mekânı aslında tanıdığını fark ettiğinde Freud'un betimlediği türden bir bastırma mekanizmasının işlediği, "heimlich" ve "unheimlich" in buluştuğu yerin tekrardan kurtulamamakla temsil edildiği söylenebilir. Tekrarın kaynağı, bastırılmış itkilerin, Freud'un "yineleme zorlantsı" dediği mekanizmayla bilinç düzeyinde çeşitli biçimlerde kendini göstermesidir (1999a: 345). Bu anlamda Gamba’nın dönüşü, bastırılmış olanın "yineleme zorlantısı"yla dönüşüdür.

Asım'ın bisikletle huzur bulma planı, ruhsal yaşamın derinlerindeki düğümlerden kurtulamadığı için başarısızlıkla sonuçlanacaktır. Nitekim Asım'ın rüyası, Gamba'nın dönüşüyle bisiklet tekerlerinin dönemeyişini buluşturur. Asım o gece Gamba'yı gördüğünde o anki yaşındadır ve sokaktan bisikletiyle geçmektedir. Biraz ileride liman ve içinde insan olmayan gemiler vardır. Rüyasında Gamba'yla karşılaşması şöyle tasvir edilir: "Bisikletini ters yöne çevirmeye çalışıyor, çeviremiyor. Üzerine binip limana doğru kaçmak istiyor ama kaçamıyor. Çünkü pedalları ne kadar çevirse de bisikleti gitmiyor. Lastikleri patlamış. Yükü o kadar çok ki, yerinden bile kıpırdayamıyor" (2006: 19). Freud'un anlattığı biçimiyle bastırma ve tekrar ilişkisini biraz daha netleştiren bu örnekten hareketle, Gamba'nın roman için anlamı, Asım'ın bireysel yaşamındaki bir travmayı temsil etmenin ötesine taşınabilir.

Freud, Uygarlğ̆ın Huzursuzluğu'nda bireyin öteki insanlarla ilişkileri üzerine düşünürken ruhsal aygitın işleyişine egemen olan şeyin "haz ilkesi” olduğunu, fakat bu ilkenin mutluluk planına "evrenin bütün oluşumları[nın] karş1 çık[tığın1]” söyler (1999b: 36). Freud bu karşı çıkışın bir sonucunu şöyle açılar: "Dar anlamda mutluluk dediğimiz şey, iyice birikmiş gereksinmelerimizin daha çok ani bir tatmini olup doğası gereği yalnızca kısa dönemli bir görüngü olarak mümkündür" (1999b: 36). Bu, Freud'a göre, insanın, bedeli sonradan ödenecek olan sürekli hazdan ziyade acıyı azaltmaya yönelik geçici hazlara yönelmesi anlamına gelir (1999b: 37). Freud, "beden," "dı̧̧ dünya" ve "öteki insanlarla ilişkilerimiz" olarak belirlediği üç temel acı kaynağından sonuncusunun insanlar üzerindeki etkisinin daha ağır olduğunu söyler: "Başka yerlerden kaynaklanan acılar kadar kaçınılmaz olsa da, bu acıyı gereksiz bir fazlalık olarak görme eğilimindeyizdir" (1999b: 37). Bu durumda "inzivaya çekilme" bir korunma yöntemi olarak kullanılır; elde edilen şey, "huzurun verdiği mutluluk"tur (1999b: 37).

Gamba'da Asım'ın bisikletiyle tek başına bir doğa yolculuğuna çıkma planı, Freud'un anlattığı türden bir huzur arayışının sonucu gibi görünür. Ötekilerin katılımıyla Asım'ın planı, her karakterin birbiriyle ilişki kurmak zorunda 
olduğu sosyal bir geziye dönüşür ve bu kez geçici mutluluk alkolde bulunur. Freud, keyif verici maddelerin "çile giderici" olarak oynadığı rolün küçümsenmeyecek derecede önemli olduğunu söyledikten sonra ekler: "İnsanlar bu maddelere yalnızca doğrudan haz elde etmeyi değil, ayrıca çok istenilen bir şeyi, dış dünyadan bağımsızlaşmayı da borçludur" (1999b: 38).

Kavukçu'nun metinlerinde çokça karşılaştığımız alkol tüketimi Gamba'da da söz konusudur. Karakterler, gezi öncesindeki yaşamlarında da alkol, özellikle bira içerler ve alkolün Freud'un sözünü ettiği dış dünyadan bağımsızlaştırma işlevi bu sahnelerde gözlemlenebilir. Asım, Cevat ve Turgay'ın iş yerinin, başkent Ankara'da, jeoloji biliminin icra edildiği ve çok sayıda mühendisin çalıştığ1 resmî bir "kurum" olarak modern ve uygar bir toplumsal düzeni temsil ettiği söylenebilir. Öğlenleri Atatürk Orman Çiftliği’ne kaçıp, bira içen "çiftlik ekibi", Freud'un gözlemlerine uygun biçimde, geçici bir "bağımsızlaşma" deneyimler. Anlatıcı, Freud'un aksine, burada amacın "keyiflenmek" olmadığını söylese de "kimliklerini sıfirlıyorlar sanki" diyerek (2006: 119) kurumun ve belki de daha genel olarak hayatın onlara biçtiği sosyal rollerden sırıldıklarını ima eder.

Alkol, uygarlığın huzursuzluğu karşısında üretilmiş bir kaçış çizgisi, geçici bir mutluluk arayışıdır. "Çiftlik ekibi”ne uyum sağlayamayan ama ekibin üyelerine alttan alta özenen Turgay bu durumu şöyle özetler:

Aslında en iyisini onlar yapıyor. Bira içip gevşiyorlar, boş şeyler konuşup rahatlıyorlar. Düzeysizlik ya da basitlik değil onlarınki; yaşamın düzeysizliğine bir tepki. Cevat'in deyişiyle 'balta muhabbetleri'. Kimsenin alınmadığı, kızmadığı ağır şakalar yapılıyor, çatlayıncaya kadar gülünüyor ve bir saatlik öğle tatili üç saate kadar uzuyor (2006: 122).

Bisiklet gezisi de sosyal bir geziye dönüştüğü an benzer bir işlev edinir ve bir taraftan doğa içinde çevrilen pedallar, diğer taraftan molalara eşlik eden alkol ve muhabbet, uygarlığın huzursuzluğu karşısında kullanılan geçici mutluluk araçları hâline gelir.

Haz ve mutluluk geçiciyken, huzursuzluk yaratan, tanımlanması zor "şey" kalıcıdır. Nitekim, "uzun paltolu, karanlık bir korku” (2006: 11) olarak tanımlanan Gamba, "gece kuşlarınınkini andıran kocaman gözler"e sahiptir; burnu yoktur; [a] ğzının olması gereken yerde ise kartalınkini andıran kocaman bir gaga" vardır (2006: 18). Asım, Gamba sözcüğünün bir anlamı olup olmadığını da bilmemektedir (2006: 11). Gamba, bu yönüyle, çocukluk dönemine ait korku ve kaygıların çocuğun imgeleminde vücut bulmasının bir sonucu olarak düşünülebilir. Asım, uzun paltolu herkesi, örneğin cüppeli imamları da birer Gamba olarak tahayyül eder ve zihninde Gamba'yı izlenme, gözetlenme ve yargılanma hissiyle ilişkilendirir (2006: 11). Bu yönüyle, Asım’ın 
psikolojik dünyasına özgü gibi görünen Gamba figürü, bizi insan doğasına dair yukarıda bahsi geçen daha genel tartışmalara taşır. Romanda Gamba, Asım'ın peşinde olsa da öteki karakterler Gamba sözcüğ̈nü Asım'ın çığl1ğ1 sayesinde duysa da Gamba'nın temsil ettiği şey, Freud'un uygar olmanın bir gereği olarak insanın bastırmak zorunda olduğunu söylediği şeylerin geri dönüşüdür.

Freud, Uygarlığın Huzursuzluğu'nda "ruhsal yaşamda bir kez kurulmuş bir şeyin yıkılamayacağı, her şeyin bir şekilde korunduğu” varsayımının içeriğini açılamak için ruhsal yaşamla Roma arasında bir analoji kurar (1999b: 29). Freud'a göre şehrin eski yapılarından pek azı kalmıştır ve bunların çoğu modern yapıların altında gömülüdür (1999b: 30). Londra gibi, Roma’dan çok daha sakin bir geçmişi olan bir şehir bile yıllar içinde birçok tahribat yaşamıştır (1999b: 31). Ruhsal yaşam da tıpkı bu şehirler gibi tahribata uğrayabilir; fakat Freud'a göre, "[s]adece ruhsal yaşamda, geçmiş olanın korunmasının garip bir istisnadan çok kural olduğu olgusuna sıkıca sarılabiliriz" (1999b: 32). Uygarlık, varlığını, itkileri kontrol altına almasına borçlu olduğundan, geçmiş, ruhsal yaşamda gömülü bir kalıntıdır. Bu durumda psikanalist "bir arkeolog gibi, gömülü olanı ortaya çıkarabilir ve kişisel bir tarihi bilinç düzeyine taşıyarak bu tarihin travmalarıyla barı̧̧mamıza, hatta tarihi yeniden inşa etmemize olanak tanır" (Schorske 1980: 53).

Gamba'da dört arkadaşın tarihî kalıntılar arasında gezdiği bir sırada Asım'ın zihninden geçenler, Freud'un kurduğu bu analojinin bir yansıması gibidir. Olympos ve Myra, karakterlerde büyük bir şaşkınlık yaratmıştır. Kaya mezarlarına dikkatle bakan Asım bu mekânla Gamba'yı özdeşleştirir. Asım'a göre Gamba, gün boyu "ölü gibi” yatan ve hava kararınca uzun paltosunu giyip düşlerine giren bir yaratıktır (2006: 205). Arkadaşlarının 1srarıly denize girdiğinde ise derinlerde "uzun paltolu tunçtan bir heykel"e benzeyen Gamba ona gülümsemektedir (2006: 211).

Bir mezarda ya da denizin dibinde "gömülü" Gamba imgesi, Freud'un bilinçdışının önemli bir parçası olarak gördüğü bastırılan şeyi temsil ederken, Gamba'nın birden denizin dibinden çıkıp kayaların tepesinde uçmaya başlaması (2006: 212), bastırılan şeyin bir imge ya da bir izlenimle dönüşünü imler. Antik kentlerin toprak ya da deniz altındaki kalıntılarına benzer biçimde ruhsal yaşam da birçok şeyi bilinçdı̧̧ına gömer; fakat Freud, bütün tahribatlara rağmen ruhsal yaşamda bir kez kurulmuş şeyin, rüyalar ya da dil sürçmeleri gibi farklı formlarda da olsa korunduğuna inanır. Gamba'nın tekrar tekrar dönüşü, uygarlığın zorunlu kıldığı bastırma mekanizmasının yarattığı huzursuz ruh hâlinin bir temsili olarak yorumlanabilir. 


\section{Yazarın Dönüşü: İç Sıkıntısı ve Teslimiyet}

Gamba'da karakterler, bisiklet ve alkolü bağımsızlaşma araçları olarak kullanırken, yolculuk öncesi hayatlarıyla bağlarını koparmak için cep telefonlarını kapatırlar. Söz konusu bağımsızlaşmanın geçiciliği ve yapaylığı, hem bu konuda birbirlerine söz vermelerinde hem de buna rağmen sözlerini tutamamalarında bir kez daha karşılık bulur. Cevat'ın merak duygusuyla cep telefonunu açması ve Şebnem tarafından arandığını görmesiyle başlayan süreç, yapay biçimde sahnenin arkasına itilen bağların hızla yeniden kurulmasıyla sonuçlanır. Asım, "[o]nu unutmak için basacağın her pedal onu biraz daha yaklaştıracak sana" diyerek bu gerçeği Cevat'ın yüzüne vururken (2006: 315), aslında hepsinin ruh hâlini özetlemektedir. Basılan pedallar, karakterleri, geçtikleri dolambaçlı yollara karşın hep aynı sokağa çıkarmaktadır.

Bütün bu dönüş hareketleriyle Gamba, Kavukçu edebiyatının en önemli özelliklerinden biri olan tema, mekân ve karakter tekrarlarını anlamlandırmaya yardımcı olur. Kavukçu, bu türden tekrarlarla örülmüş, yalnızca münferit metinler olarak değil, bütünlüklü bir kitap olarak da okunabilen döngüsel öyküler (cycle stories) yazmakla kalmamış, neredeyse bütün yapıtlarında, yazarın öteki yapıtlarına aşina bir okurun tanıyabileceği öğelere yer vermiştir. Örneğin, Ankara'da yaşayan üç karaktere katılan Nurbay'ın kasabaya sıkışıp kalmışlı̆̆ının ve Almanya macerasına karşın kasabaya dönen İlhan'ın can s1kıntısının anlatıldığı bölümlerin benzerlerine Kavukçu'nun birçok metninde rastlanabilir. İlhan Almanyaya gitmeden önceki gece beş arkadaş Çınaraltı Meyhanesi'nde içmiş, hesabı Necmettin'in Konyakçı adını verdikleri babası ödemiştir (2006: 59). Kavukçu edebiyatı, dostların içerek taşra sıkıntısından ve bir kaçış çizgisi yaratma umudundan konuştuğu onlarca sahne içerir. Gamba'da özellikle İlhan'ın deneyimleri, yazarın yapitlarındaki "dört duvar" ve "Angelacoma'nın duvarları" gibi kıstırılmış duygusunu ifade eden imgelerle anlat1lir.

Ayrıca İlhan, Kavukçu yapıtlarında, özellikle de gemi adamlarının ve meyhane muhabbetlerinin anlatıldığ öykülerde karşılaştığımız iyi hikâye anlatıcılarından biri olarak tasvir edilir: "Onun öykülerini başkaları anlattığında bile gülüyorlar. Ama İlhan'dan dinlemeliydiler. Yüzünü, gözlerini, sesini, ellerini öylesine ustalıkla kullanıyordu ki, gerçeklerle bağdaşmayan en uçuk öyküsüne bile bir inandırıcılık katıyordu” (2006: 48). Kasabadaki gençlerin Necmettin'in babasına verdikleri "Konyakçı" adı da Kavukçu'nun çizgi roman kahramanlarına sık sık yer açan imgelemine aşina okur için şaşırtıcı değildir. Semih Gümüş’ün Gamba'yı değerlendiren yazısının başlığının “Öykücünün Romanı” olmasının nedenlerinden biri de romanın birçok yerde yazarın öykülerini çağrıştırmasıdır. Gümüş bu tespiti vurgulamak için dil ve üslup benzerliğinden de söz eder: "Bu romanın sonunda Gamba'nın Cemil 
Kavukçu'nun öykülerini yaratma biçiminden adamakıllı beslendiğini, birbirinden ayrı tasarlanmış bölümleri öykülerindeki dil ve söz yapısıyla kurduğunu saptayabiliriz" (2008: 198-99).

Bununla beraber Gamba, yazarın öteki romanları, Dönüss ve Suda Bulanık Oyunlar'la da güçlü bir diyalog sürdürür. Baştan sona "dönüş" motifi etrafinda şekillenen Gamba, Dönüş'teki kasaba-kent ikilemi, iç sıkıntısı, iletişimsizlik gibi temaların yanında romanın baş kişisi Vedat'ın bisikletle kurduğu ilişki nedeniyle de Dönüş'e oldukça yakındır. Vedat, 1980 öncesinin çalkantılı döneminde inandığı değerlerle, kaybetmekten korktuğu geleceği arasında kalmış, ailesini, arkadaşlarını ve sevdiği kadını bütün bu karmaşa içinde kaybetmiş ve kendisini yıllar sonra çocukluğunun geçtiği kasabada bulmuştur. Kendisiyle yüzleşmeye, geçmişiyle hesaplaşmaya geldiği kasabada evin odunluğunda bulduğu eski bisikletini herhangi bir nesne olarak değil, "onunla birlikte soluyan bir can” olarak düşünür (1998: 40). Vedat'n Doğusulak Köyü’ne bisikletle gidişinin ayrıntılarla anlatıldığı on ikinci bölümde yokuş çıkmak, Gamba'da olduğu gibi, sınırları zorlamak, hafiflemeye çalışmak anlamına gelir. Gamba'da Asım'ın söylediği "bunalan ruh hareket ister" sözünün neredeyse aynısını Dönüş'te Vedat kendisine telkin etmektedir: "Çok mu yükleniyorum kendime? Bak soluk soluğayım, kalbim nasıl da çarpıyor. Olsun, daralmış ruh hareket ister. Hareket, hareket ister" (1998: 115). Kendisini, içini sıkan her şeyden kurtaran geçici bir özgürleşmedir bisiklet. Yürümenin, resim yapmanın, yazmanın sıkıntısını azaltmadığı durumlarda çözümü pedallara basmakta bulur: "[B]isikletine atladığı gibi pedallara basıyor. Her şey o ç1lgın iniş için; bireysel bir seçim bu, bir tür özgürlüğün ifadesi” (1998: 130).

Vedat, özgürleşme umuduyla pedallara basarken, yolun kenarında "bulanık bir dere" kıvrilarak akmaktadır (1998: 114). Yol boyunca Vedat'ın bir sağında, bir solunda beliren bu dere, Dönüş'te kasabaya dair iç sıkıntısının bir sembolü gibidir. "Burada her şey çamur renginde; ben bile" (1998: 115) diyen Vedat, bu bulanıklığın kaynağının bir köhnelik hâli, dar bir çember içinde sıkışıp kalmışlık ve geleceği görememek olduğunu düşünmektedir. Kavukçu, Dönüş'ten altı yıl sonra yayımlanan ikinci romanında "bulanık su" imgesini anlatısının merkezine yerleştirecektir. Bu kez Tarık'n içsel yolculuğunu, siyasi çalkantılar arasında bireysel dertlerini çözme uğraşını okuruz. Roman, Tarık’ın Kırat adını verdiği, kentin bütün pisliğini barındıran çayın tasviriyle aç1ır. Dönüş'te olduğu gibi Suda Bulanık Oyunlar'da da bulanık su imgesi, bir ruh hâlini ve bir atmosferi anlatmak için kullanılır. "İşte, gönlüm gibi bulanık sular, diyor Tarık. Zamandı, yaşamdı, geçiyor işte gözünün önünden; bozbulanık, utanmazca" (2004: 10).

Her iki romanda da karakterlerin aşk ve cinsellik gibi çözümsüz kalan dertlerinin yanında 1980 öncesinin siyaseten kaotik ortamında yaşadıkları kimlik 
bunalımları ve gerilimler de söz konusu bulanıklığın nedenleridir. Gamba’nın bu iki romanla diyaloğunun en can alıcı örneklerinden biri de "bulanık su" imgesinin söz konusu siyasi ortamın bir sembolü olarak bu romanda da belirmesidir. Asım'ın son iş gününde çekmecesinde bulduğu ve yıllar önceki bir arazi çalışması sırasında tuttuğu "Çayırlı Notları" adlı arazi defterinde 1980 darbesi de yer alır. 12 Eylül günü Asım, Çayırlı'dadır, Ankara'daki eşi Nezahat için endişelenir. Bu notlar da tıpkı Dönüşve Suda Bulanık Oyunlar'da olduğu gibi, bireysel dertleri, bu durumda söz gelimi Asım'ın bir mühendis olarak yaşadığı yetersizlik hissini yansıtmakla beraber, "bulanık su" imgesinin, romanın siyasi tarihe açık bir gönderme yaptığı tek bölüm olan Çayırlı Notları'nda karşımıza çıkması, öteki romanlarla yakın ilişkisinin bir örneğidir. Asım ekiptekilerle beraber balı̆ga çıktığında, derenin bulanık suyuna fenerin 1şı̆̆ını tutup balıkları oraya toplamak isterler fakat başarılı olamazlar. Çayırlı Notları şöyle devam eder: "Sonra diyoruz ki, bu su bulanık, diyoruz. Daha aşağılarda bulanık olmayan sular da var, diyoruz... Aptal balıkların orada yaşadığına ve bizi beklediğine inandırıyoruz birbirimizi” (2006: 222-23). Özetle bulanık sular, Kavukçu'nun roman karakterlerinin iç sıkıntılarının tekrar eden bir motifi olarak söz ettiğimiz döngülere eklemlenir.

Gamba'da tematik ve biçimsel boyutlarıyla sergilenen bu dönüş ve tekrarların Kavukçu'nun yazma motivasyonuyla ilişkisinin odağına "sıkıntı" duygusu yerleştirilebilir. "Yazma Sıkıntısı" başlıklı denemesinde Kavukçu, "sıkıntı"yı edebiyat üretiminin kaynağı olarak gördüğünü söyler ve bu duygunun tekinsizliğini vurgular: "[İ]çinde büyüttüğün sana çok benzeyen aynı zamanda çok yabancı biridir bu" (2013: 33). Kavukçu, beynin rahmine düşen bu tohumun sonunda bir "canavar" olarak dünyaya geldiğini söyler ve ekler: "Onunla baş başa kaldığında seni içdenizinin derinliklerine çeker" (2013: 33). Kavukçu'nun yazma sıkıntısını anlatmak için kullandığı bu imge, Asım'1 denizin derinliklerine çeken Gamba'yı çağrıştırır. Üstelik tıpkı Gamba gibi, yazma sıkıntısı da 1srarc1, hatırlatıcı ve ele geçiricidir: "Unutmak istediklerini, karga sürüleri gibi başının üstünde toplayan odur. Öylesine köşeye sıkışırsın ki, 'Tamam,' dersin, 'teslim oluyorum.' O zaman içindeki canavar senin yerine geçer, "sen" olur ve tepende dönüp duran kargaları dağıtmak için şehvetle yazar. Bu buluşma 'muhteşem bir tufan'dır”' (2013: 33).

Kavukçu'nun resmettiği bu yazma ânında sıkıntının baskısıyla bir dönüşüm gerçekleşmekte, yazar, üretmek için canavarlaşmaktadır. Uygarlığın Huzursuzluğu'nda Freud'un "yüceltme” adını verdiği, dürtülerin sanatsal eylemlere kanalize edilmesi durumunu (1999b: 55) çağrıştıran bu dönüşümde köşeye sıkışan yazar, çemberin dışına çıkamayacağını anlayınca teslim olmakta ve bir çıkış yolu olarak yazıya yönelmektedir. Ölüm iç güdüsüyle yaşam 
iç güdüsünün buluştuğu kaotik bir andır bu. Kavukçu'nun neredeyse bütün metinlerinde karşımıza çıkan kargalar, bu resimde yazarın unutmak isteyip de unutamadıklarını simgeler. Gamba ise Asım’a "kartal gaga”sındaki "her şey bitti” gülüşüyle bakarken "paltosunun eteklerini kanat gibi" açmıştır (2006: 212).

Asım, Jale Parla'nın Türk Romanında Yazar ve Başkalaşım başlıklı çalışmasında çözümlenen yazar figürasyonlarına örnek teşkil edecek türden ayrıntılı veriler sunmaz. ${ }^{1}$ Bununla birlikte, Asım'ın “Çayırlı Notları"nı yazma sebebinin Kavukçu'nun yazma sebebi olarak öne sürdüğü "sıkıntı” yla ortaklığı dikkate değerdir. Günlük tutmak gibi bir alışkanlığı olmadığı hâlde, Çayırlı'da yaşadığı iç sıkıntısı, Asım'ı o günlerde yazmaya itmiştir (2006: 236). Bunun dışında Asım'ın yazıyla ilişkisinde Kavukçu'nun kendi yazma deneyimini anlattı̆̆ türden bir dönüşümün izi sürülemez. Kavukçu'nun sözünü ettiği canavaryazarla Gamba arasındaki ortaklık, her ikisinde de tanıdık, bilinen bir şeyin (heimlich) bastırılması ve bastırıldığı için yabancı ve tuhaf (unheimlich) hâle gelmesidir. Nasıl Kavukçu sıkıntı duygusunu kişileştirerek hem çok tanıdık hem de çok yabancı "biri” olarak tanımlıyorsa, Gamba da bastırılmış dürtülerin uyandırdığı, "vücut bulan" duygular olarak düşünülebilir.

"Paltosunun eteklerini kanat gibi açan" Gamba imgesinin yazarın sıkıntı duygusuyla ilişkisini açımlamak amacıyla Dönüş'teki bir sahneden yararlanmak mümkündür. Vedat'ın Doğusulak Köyü'nün rampalarına kendini özgürce bıraktığı an şöyle tasvir edilir: "Pedalları daha hızlı çeviriyor. Caddeleri, sokakları uçarcasına geçiyor. Paltosunun etekleri birer kanat gibi açılmış” (1998: 138). Vedat'ın kasabanın zorlayıcı sınırlarından çıkma çabasını resmeden bu sahnede palto, artık omuzların üzerindeki yük değil, Vedat'ın özgürleşmesini sağlayacak kanatlı bir kuştur. Roman boyunca Vedat'ın paltosu olayların akışını resmetmekte kullanılan sıradışı bir nesne olarak belirir. Vedat, ergenlik döneminde delikanlılığını arkadaşlarına kanıtlamak için palto giymezken (1998: 19), üniversite yillarında siyasi duruşunun sembolü bir parka giyer (1998: 99). Dönüş yolculuğu boyunca ise defalarca paltosunu giyer ve çıkarır. Palto, etekleri çamurlanan (1998: 76), yırtmacı selenin iki yanından sarkan (1998: 117), cebinde kanyak şişesi saklanan $(1998: 79,116)$, koluna, mezarlıkta dökülen gözyaşlarının silindiği (1998: 79) bir nesne olarak farklı işlevleri yerine getirir.

1 Jale Parla, Ahmet Mithat'tan Orhan Pamuk'a uzanan tarihsel süreçte romanlardaki mükemmel, yarım, eksik, başarısız ya da âciz yazar figürlerini incelediği çalışmasında, yazan roman kişilerinin yaşadığ1 başkalaşımları ele alır. Gamba'da Asım, bir günlük yazarı olarak karşımıza çıksa da bu makalenin tartışmaya açtığı yazma ve başkalaşım ilişkisinin temel kaynağı, Kavukçu'nun "Yazma Sıkıntısı" başlıklı denemesidir. 
Çocukluk ve ergenlikte belli var oluş tarzlarını işaret eden sosyal bir simgeyken, Vedat'ın kasabaya "dönüş" sürecinde palto, başlangıçta çemberin ağırlığını hissettiren, sonrasında ise kanatlarıla özgürleştiren bir nesnedir. Böylelikle Gamba’nın "her şey bitti” gülüşüyle paltosunun kanatlarını açmasının, yazarın daha fazla dayanamayarak "sıkıntı" hissine teslim olup canavarlaşmasının ve Vedat'in omzundaki yükü özgürleşmek için kullanmasının ulaştığ 1 nokta aynıdır: Dışına çıkılması imkânsız bir çemberin içinde var olmanın tek yolu, çemberin sınırlarını zorlamaktır. Bu, bireyin toplumsal bir varlık olarak istese de geride bırakamadığı bağlardan kaynaklanan bir çember de olabilir, Freud'un "yineleme zorlantısı" adıyla kavramsallaştırdığı, bastırılanın dönüşünden kaynaklanan bir kıstırılmışlık duygusu da.

Gamba'nın çeşitli biçimlerde sahnelediği her iki durum da bizzat Kavukçu'nun benzer tema ve motiflere dönüşünün arkeolojik bir kazı nesnesi olduğu izlenimi vermektedir. ${ }^{2}$ Kavukçu, 2015'te yayımlanan O Vakit Son Mimoza kitab1nın başlığıyla bile kendisine adeta tekrar tekrar yazdığ Mimoza Meyhanesi öykülerinin artık bitmesi gerektiğini telkin etmektedir. Oysa Kavukçu'nun yaptığı, çemberi her seferinde içeriden zorlamak, hatırlatıcı kargaları başının üstünde döndürüp duran o ısrarcı şeyi yazmaktır. Nasıl Gogol'ün paltosundan yüzlerce farklı yazar çıktıysa Kavukçu'nun paltoları da kanatlanarak çemberin içindeki özgürleşme olanaklarını duyumsatır.

\section{Sonuç}

Dört arkadaşın bisikletle çıktıkları yolculuğun etrafında şekillenen Gamba'da, Kavukçu'nun öteki metinlerinde de karşılaştığımı "dönüş" motifi merkezî bir rol oynar. Karakterlerin pedalları çevirerek döndürdükleri tekerler, Asım’ın tam olarak tanımlayamadığı bir yaratık olan Gamba'nın dönüşü ve dört arkadaşın sıkıldıkları için geride bıraktıkları hayatlarına dönüşü, karakterlerin bireysel tarihlerinin ve travmalarının yanında uygarlığın huzursuzluğunu da sahneler. Bir denizcilik terimi olarak, "iyi toplanmamış halat veya zincirlerde ortaya çıkan dolaşıklık" anlamına gelen "gamba” sözcüğünün (TDK Sözlüğü) romanın başlı̆̆ı olarak ima ettiği şey, içselleştirilemediği için üstesinden gelinemeyen bir özgürlük fikrinin peşinden gitmekten kaynaklanan yapaylık ve beceriksizliktir.

2 Kavukçu'nun tekrarlarını, yazarın sürekli kendini yinelemesi, kısır bir döngüye girmesi olarak değerlendirenler de vardır. Bu türden bir okur tepkisi örneği olarak, Öykülem dergisinin dördüncü sayısındaki "Herkes Burada Kimse Yok" başlıklı söyleşide Eyüp Tosun’un söylediklerine bakılabilir: "[B]en mesela artık Cemil Kavukçu okumamaya karar verdim. Çok sevdiğim bir öykücüdür. Üstü Kalsın’ı da severek okudum ama hep aynı şeyleri hep aynı şekilde anlatıyor ve sıkıldım artık" (2016: 41). 
Bununla beraber roman, gömülü olduğu için insana dair gizli kalan alanların ancak arkeolojik bir kazıyla ortaya çıkarılabileceği gerçeğinin temsili olarak okunabilecek birçok epizot içerir. Bu temsillerin en önemli araçlarından biri olan tekrar ise Kavukçu'nun benzer karakter, mekân ve temalara dönüşünü de anlamlandırmaya yardımcı olur. Yazarın, bir denemesinde edebi yarat1c1lıkla sıkıntı arasında kurduğu ilişkiyi açıklamak için başvurduğu imgeler, Gamba'da sahnelenen kıstırılmışlik duygusuyla, sıkıntıya kendini teslim eden yaratıcı yazarın deneyimi arasında ilişki kurmaya olanak tanır. Her iki durumda da bastırılanın dönüşü karşısında yaşanan şey, bilinen bir sokakta kaybolmaya benzer. Yaratıcılık, gücünü, bu kayboluş içinde, çemberin sınırlarını zorlayan bir canavarlaşmadan alır.

Sonuç olarak, Gamba'da "dönüş" motifinin izi sürüldüğünde Freud'un bilinçdışı kavramının Kavukçu edebiyatı açısından önemi açık hâle gelir. Bir taraftan roman karakterlerinin kent ve kasabadaki kıstırılmışlı̆ının, diğer taraftan yaratıcı yazarın üretme arzusunun yarattığı sıkıntı duygusu, psikanalizin "tekinsizlik", "yineleme zorlantısı" ve "uygarlığın huzursuzluğu" kavramları aracılığıyla yorumlanabilir. Gamba'da bastırılanın dönüşünün tematik ve edebî yansımaları, Kavukçu yapıtları üzerine yapilan çalışmalarda vurgulanan yalnızlık ve yabancılaşma izleklerine psikanalitik kavramlarla yaklaşmanın yeni bir bakış açısı sağlayabileceğini göstermektedir.

Adler, Nancy J (2012). The Bicycle in Western Literature: Transformations on Two Wheels, yayımlanmamış yüksek lisans tezi, Rollins College, (http://scholarship.rollins.edu/mls/22, Erişim tarihi: 08.05.2016).

Eren, Zerrin (2008). "Cemil Kavukçu'nun Üç Öyküsünde 'Metinlerarası Çerçeve'Uygulaması”, Beşinci Pencere: Cemil Kavukçu Kitabı, Der. Melike Koçak, İstanbul: Can Yayınları, s.87-99. (Yazı ilk kez Mart-Nisan 2000 tarihli Adam Öykü dergisinde yayımlanmıştır.)

Freud, Sigmund (1999a). "Tekinsiz", Sanat ve Edebiyat, Çev. Emre Kapkın ve Ayşen Tekşen Kapkın, İstanbul: Payel Yayınevi, s.321-359. (Yazının “Das Unheimliche” başlıklı orijinali ilk kez 1919'da yayımlanmıştır.)

(1999b). Uygarlı̆̆ın Huzursuzluğu, Çev. Haluk Barışcan, İstanbul: Metis Yayınları. (Kitabın Almanca orijinali Das Unbehagen in der Kultur ilk kez 1930'da yayımlanmıştır.)

“Gamba”, Sözlük Maddesi, Türk Dil Kurumu Güncel Türkşe Sözlük (http:// www.tdk.gov.tr, Erişim tarihi: 08.05.2016).

Gümüş, Semih (2008). “Öykücünün Romanı”, Beşinci Pencere: Cemil Kavukçu Kitabı, Der. Melike Koçak, İstanbul: Can Yayınları, s.196-203. (Yazı ilk kez 20 Ocak 2006 tarihli Radikal Kitap’ta yayımlanmıştır.) 
“Herkes Burada Kimse Yok” (2016). Söyleşi (Eyüp Tosun, İlker Aslan, Mustafa Orman, Orçun Ünal), Öykülem 4, s.35-50.

Kavukçu, Cemil (1998). Dönüs, İstanbul: Can Yayınları. (2006). Gamba, İstanbul: Can Yayınları. (2004). Suda Bulanı Oyunlar, İstanbul: Can Yayınları. (2013). "Yazma Sıkıntısı", Örümcek Kapanı, İstanbul: Can Yayınları, s.33-35.

Koçak, Melike (2008). "Cemil Kavukçu Öyküleri Kimleri, Nereleri, Neleri, Nasıl Anlatır?”, Beşinci Pencere: Cemil Kavukçu Kitabı, Der. Melike Koçak, İstanbul: Can Yayınları, s.13-29.

Parla, Jale (2011). Türk Romanında Yazar ve Başkalaşım, İstanbul: İletişim Yayınlar1.

Raab, Alon (Eylül-Ekim 2012). "Wheels of Fire: Writers on Bicycles”, World Literature Today, Vol.86, No.5, s.22-31, (http://www.jstor.org/stable/10.7588/worllitetoda.86.5.0022, Erişim tarihi: 08.05. 2016).

Schorske, Carl E. (1980). "Freud: The Psycho-archeology of Civilizations", Proceedings of the Massachusetts Historical Society, Third Series, Vol.92, s.52-67, (http://www.jstor.org/stable/25080867, Erişim tarihi: 19.05.2016).

Tanritanır, Bülent Cercis ve Burcu Tütak (2015). “J.D.Salinger'ın Çavdar

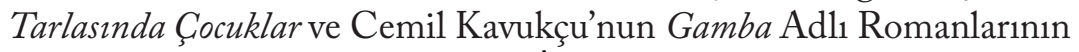
Yabancılaşma Kavramı Ekseninde İncelenmesi”, The Journal of Academic Social Science Studies 38, s.19-35. 


\section{ABSTRACT \\ From Bicycles to Cycles: Return and Transformation in Gamba}

Cemil Kavukçu, one of the most prolific writers of contemporary Turkish literature, published his novel Gamba in 2005. The novel revolves around four characters who set off a trip into nature on their bikes to emancipate themselves from the burdens of their prosaic lives, but end up "returning" to their ordinary life spaces after a little while. The theme of "return," which can be traced in many works of Kavukçu, finds its reflection in Gamba in three movements of (re) turning that can be treated both thematically and figuratively: the turning of bicycle wheels; after many years, the return of Gamba, a creature that used to haunt a character's dreams in his childhood; and finally the characters' fast return to their pre-journey lives. Analyzing psychological and social dynamics of these movements, this article suggests that Gamba can also be considered a stage which may help us understand Kavukçu's cycle stories. The article approaches the themes of loneliness and alienation, which have often been emphasized by Kavukçu scholars, from a psychoanalytic perspective. It relates these three movements, which represent not only the characters' individual histories, but also the "discontents of civilization," to the feeling of distress. Kavukçu regards this sense as the source of literary production in his essay, "Yazma Sikıntısı" ("The Distress of Writing"). In this context, the psychic life staged in Gamba and explored by Freud through such concepts as "the return of the repressed," "repetitive compulsion," and "uncanny," may explain the dynamics of the moment of writing pictured by Kavukçu. As a result, the article suggests that both Kavukçu's repetitive returns to similar characters, settings and themes and the (re)turns in Gamba may be considered in similar frameworks. Accordingly, in both of them the only way to survive in a circle, which hardly lets anybody out, is to push its limits from within.

Keywords: Return, transformation, repetition, discontents of civilization, uncanny, Sigmund Freud, Cemil Kavukçu, Gamba 
